\title{
Agro-economic efficiency in radish-arugula intercropping as a function of green
}

\section{manuring and population density}

\section{Eficiência agroeconômica no consórcio de rabanete e rúcula em função da adulbação verde e densidade populacional}

Eficiencia agroeconómica en el consorcio de rábano y arugula en función del abono verde y la densidad de población

Received: 04/09/2021 | Reviewed: 04/13/2021 | Accept: 04/14/2021 | Published: 04/27/2021

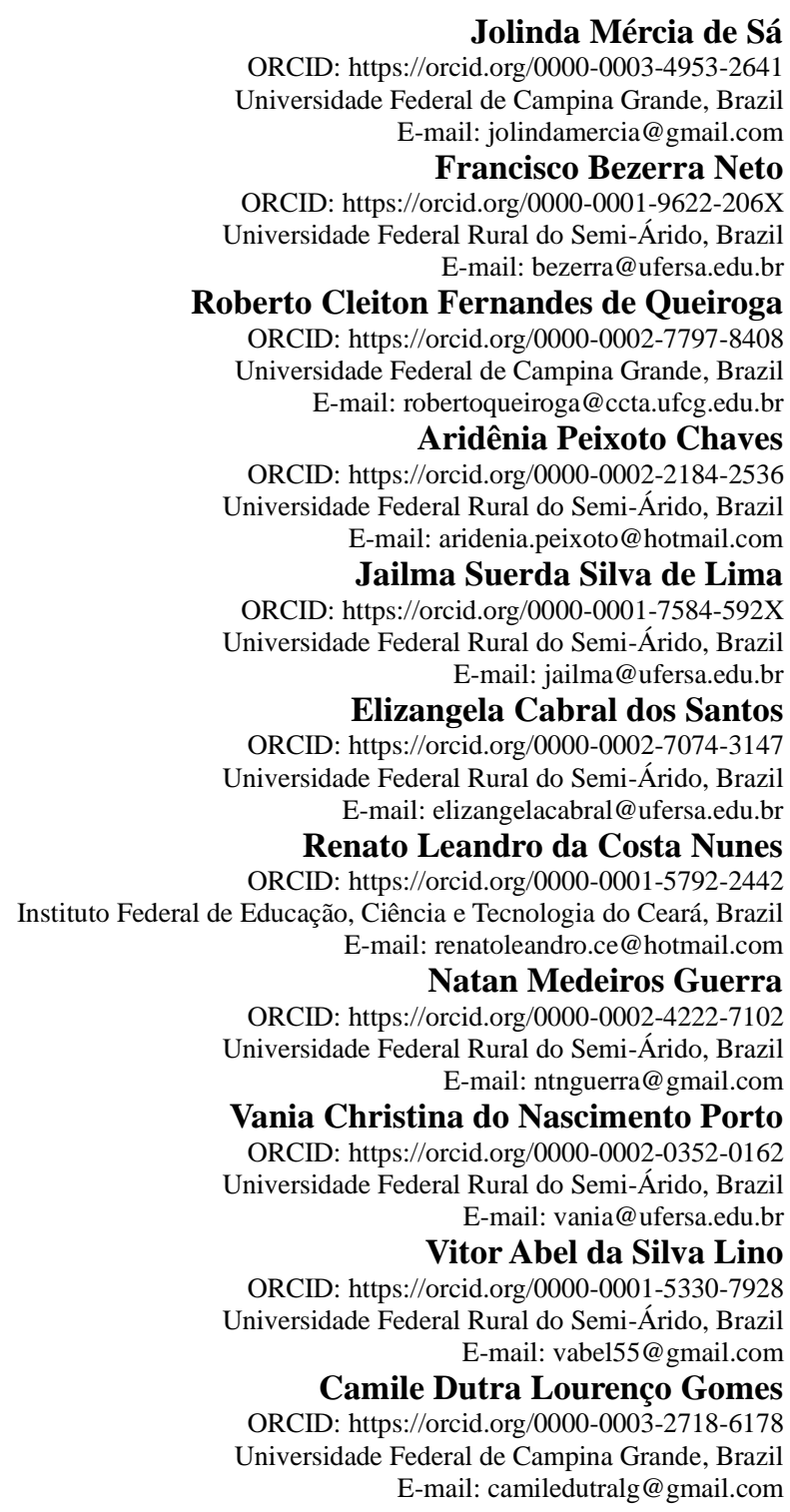

\begin{abstract}
The vegetables intercropping practice triumph in family farming depends on several production factors, including the crops involved, green manuring and plant density of component crops. Therefore, the aim of this work was to assess whether there is agro-economic viability in the radish-arugula intercropping, in different equitable amounts of $M$. aegyptia and $C$. procera biomass $\left(20,35,50\right.$ and $65 \mathrm{t} \mathrm{ha}^{-1}$ on base dry) and in diverse arugula population densities (40,
\end{abstract}


60, 80 and $100 \%$ of that recommended density for single crop - RDSC), combined with $100 \%$ of the RDSC for radish in two cropping years. The characteristics, the commercial productivity of radish roots and the arugula green mass yield were evaluated and in the intercropped system, the agronomic indices: land equivalent ratio (LER), intercropping advantage (IA), actual yield loss (AYL), productive efficiency index (PEI), score of the canonical variable (Z), and the economic indicators: gross income (GI), net income (NI), rate of return (RR) and profit margin (PM). The greatest agro-economic advantages of the radish-arugula intercropping were achieved with an LER of 1.64, PEI of $0.86, \mathrm{Z}$ of 1.54 , GI of R $\$ 45,543.92 \mathrm{ha}^{-1}$, NI of R $\$ 24,662,31 \mathrm{ha}^{-1}$, RR of R $\$ 2.20$ for each real invested, and PM of $56.37 \%$, respectively, in the combination of $65 \mathrm{t} \mathrm{ha}^{-1}$ of $M$. aegyptia and C. procera biomass and arugula population density of $100 \%$ of the RDSC, corresponding to the density of 1 million plants per hectare.

Keywords: Raphanus sativus; Eruca sativa; Merremia aegyptia; Calotropis procera; Feasibility.

\section{Resumo}

O sucesso da prática da consorciação de hortaliças na agricultura familiar depende de diversos fatores de produção, incluindo as culturas envolvidas, a adubação verde e a densidade de plantas das culturas componentes. Portanto, o propósito deste trabalho foi avaliar se há viabilidade agroeconômica no consórcio rabanete-rúcula, em distintas quantidades eqüitativas de biomassa de $M$. aegyptia e $C$. procera $\left(20,35,50\right.$ e $65 \mathrm{t} \mathrm{ha}^{-1}$ em base seca) e em diversas densidades populacionais de rúcula $(40,60,80$ e 100\% da densidade recomendada para cultivo solteiro - DRCS), combinadas com $100 \%$ da DRCS do rabanete em dois anos de cultivos. Foram avaliadas as caracteristicas, produtividade comercial de raízes de rabanete e a produção de massa verde de rúcula e, no sistema consorciado, os índices agronômicos: razão equivalente de terra (RET), vantagem do consórcio (VC), perda real de rendimento (PRR), índice de eficiência produtiva (IEP), escore da variável canônica (Z) e os indicadores econômicos: renda bruta (RB), renda líquida (RL), taxa de retorno (TR) e índice de lucratividade (IL). As maiores vantagens agroeconômicas do consórcio rabanete-rúcula foram alcançadas com RET de 1,64, IEP de 0,86, Z de 1,54, RB de R\$ 45.543,92 ha-1, RL de R\$24.662,31 ha-1, TR de R\$2,20 para cada real investido, e IL de 56,37\%, respectivamente, na combinação de $65 \mathrm{t} \mathrm{ha}^{-1}$ de biomassa de $M$. aegyptia e $C$. procera e densidade populacional de rúcula de $100 \%$ do DRCS, correspondente à densidade de 1 milhão de plantas por hectare.

Palavras-chave: Raphanus sativus; Eruca sativa; Merremia aegyptia; Calotropis procera; Viabilidade.

\section{Resumen}

El éxito de la práctica de la asociación de hortalizas en la agricultura familiar depende de varios factores de producción, incluidos los cultivos involucrados, el abono verde y la densidad de plantas de los cultivos que lo componen. Por lo tanto, el objetivo de este trabajo fue evaluar si existe viabilidad agroeconómica en el consorcio

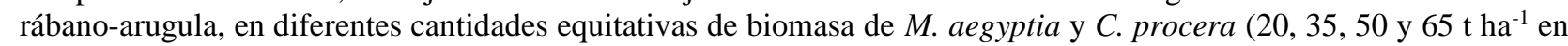
base seca) y en diversas densidades de población de rúcula (40, 60, 80 y 100\% de la densidad recomendada para un solo cultivo - DRSC), combinada con el $100 \%$ del DRSC de rábano en dos años de cultivo. Se evaluaron las características, productividad comercial de las raíces de rábano y la producción de masa verde de arugula y, en el sistema asociado, los índices agronómicos: relación equivalente de tierra (RET), ventaja del consorcio (VC), pérdida real de rendimiento. (PRR), índice de eficiencia productiva (IEP), puntaje de variable canónica (Z) e indicadores económicos: ingreso bruto (RB), ingreso neto (RL), tasa de retorno (TR) e índice de rentabilidad (IL). Las mayores ventajas agroeconómicas de la asociación rábano-rúcula se lograron con RET de 1,64, IEP de 0,86, Z de 1,54, RB de $\mathrm{R} \$ 45.543,92 \mathrm{ha}^{-1}$, RL de R\$ 24.662,31 ha-1, TR de R\$ 2,20 para cada uno real invertido, e IL de 56,37\%, respectivamente, en la combinación de $65 \mathrm{t} \mathrm{ha}^{-1}$ de biomasa de $M$. aegyptia y $C$. procera y densidad poblacional de arugula de $100 \%$ de la DRCS, correspondiente a la densidad de 1 millón de plantas por hectárea.

Palabras clave: Raphanus sativus; Eruca sativa; Merremia aegyptia; Calotropis procera; Viabilidad.

\section{Introduction}

The vegetables production is an intensive agricultural activity, which demands a high technological contribution, large areas of land, abundant water and constant labor, so as to obtain products of better quality and competitive prices in the market. This modern production has been practiced in an expressive way by small family farmers, presenting great social and food importance for the Brazilian regions, as well as providing job and income generation. This production system involves different aspects of the production chain, such as organic inputs, infrastructure and trade, and must be managed with competence to obtain good results and produce at low economic and environmental costs (Cecílio Filho et al., 2015).

The intercropped systems are among the agricultural practices used successfully by small vegetable producers and show gains in productivity and nutritional, economic and environmental value (Almeida et al., 2015; Andrade Filho et al. 
2020). However, the advance of this practice depends on several factors that are associated to the crops involved, such as the plant density of the cultures and green manuring.

The radish and arugula have been identified as companion crops when planted in intercropping (Hata et al., 2019; Rezende et al., 2009), as they have distinct morphological architectures and ecological niches that maximize the light utilization and water absorption and nutrients, when compared to their monocultures in a given area; promote the suppression of pests and diseases, provide greater productivity per planted area and biological diversification of the environment (Meira et al., 2012).

In the evaluation and recommendation of systems intercropped with companion crops, several agronomic/biological indices and economic indicators have been used (Mello \& Gomes, 2013; Gebru, 2015; Cecílio Filho et al., 2015; Silva et al., 2017; Diniz et al., 2017). Among the agronomic/biological indices are: land equivalent ratio (LER), actual yield loss (AYL), intercropping advantage (IA), productive efficiency index (PEI) and score of the canonical variable (Z). These indices provide accurate results regarding the cultures performance and mainly of the intercropping, with which it is possible to safely compare the intercropping suitability in relation to single cropping.

The evaluation of the intercropping economic viability can be performed through indicators based on costs and benefits called economic indicators (Bezerra Neto et al., 2010; Lima et al., 2007; Nunes et al., 2018). These include gross and net incomes, the rate of return, and the profit margin (Lima et al., 2014; Oliveira et al., 2012).

Therefore, this work had the purpose of evaluating the agro-economic efficacy of the radish with arugula intercropping, in diverse arugula population densities and equitable amounts of biomass of green manures $M$. aegyptia and $C$. procera, in two cropping years.

\section{Methodology}

The preparation, the experimental procedure and the methodology for conducting field experiments about the radish and arugula intercropping, as well as of the use of materials to carry out this research, followed the methodologies developed by Batista et al., 2016; Oliveira et al., 2015 and Batista et al., 2013.

\subsection{Sites and climate}

The work was carried out at the Rafael Fernandes Experimental Farm, located at the Universidade Federal Rural do Semi-Árido (UFERSA), $20 \mathrm{~km}$ away from the headquarters of the municipality of Mossoró, Rio Grande do Norte, Brazil. Two experiments were conducted, the first in the period from October to December 2018 and the second in the period from June to August 2019. The climate in this region, according to the Köppen classification, is BShw, dry and very hot, with two seasons: a dry season normally occurring from June to January, and a rainy season from February to May (Alvares et al., 2014). During the conduct of the experiments, the recorded average values of minimum and maximum temperatures, relative humidity and precipitation for the years 2018 and 2019 were respectively: 27.4 and $25.7{ }^{\circ} \mathrm{C} ; 28.5$ and $27.0{ }^{\circ} \mathrm{C} ; 67.0$ and $72.2 \%$ and 0 and $32.3 \mathrm{~mm}$. Figure 1 shows the daily values of minimum and maximum temperatures and relative humidity for each cropping year of the intercropping of radish and arugula. 
Figure 1. Climatic data provided by National Meteorological Institute during the experimental period of the 2018 and 2019 cropping years.
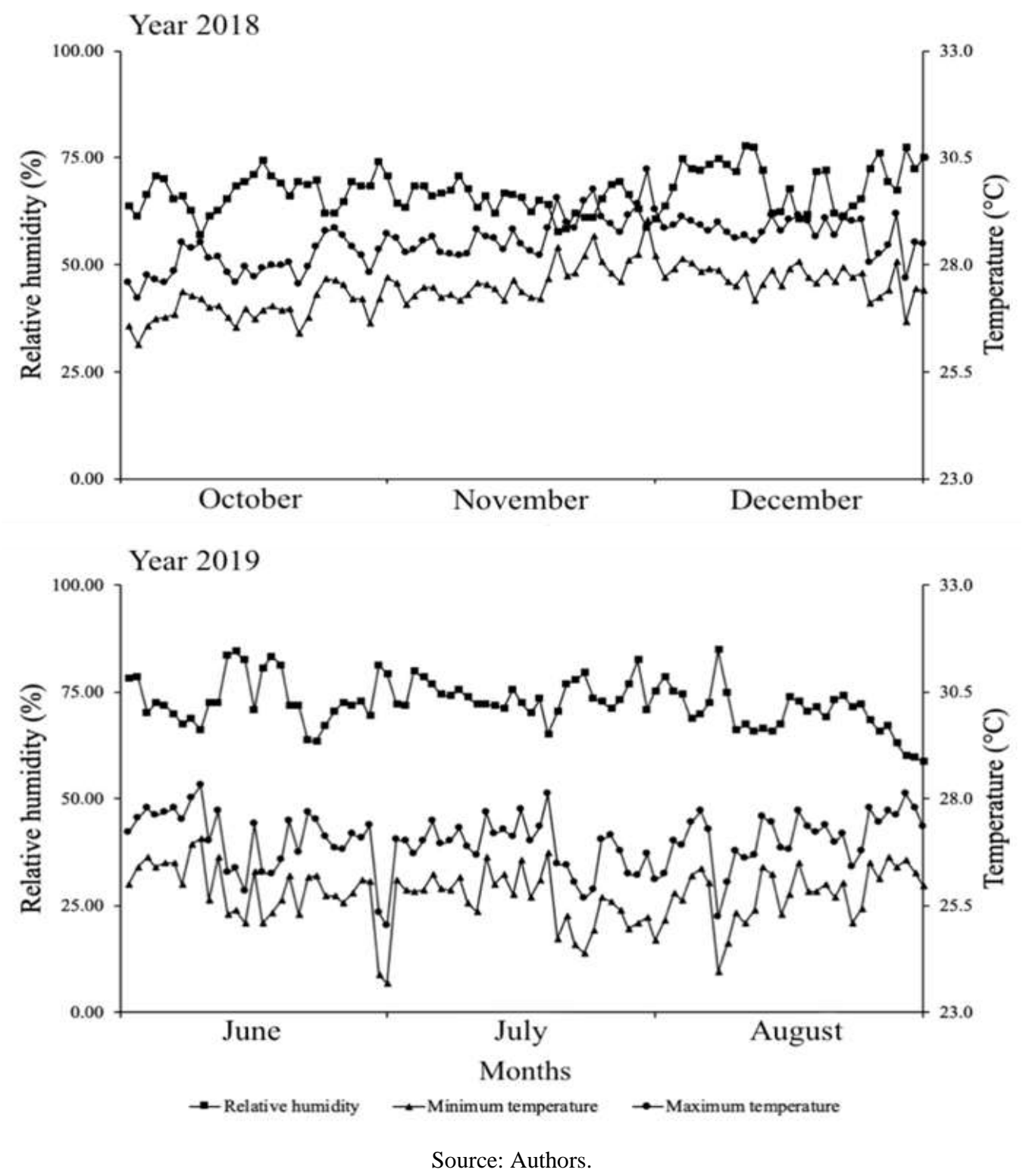

The soils in the experimental area were classified as a typical dystrophic Red Argisol (Rêgo et al., 2016). Samples of these soils were collected in the 0-20 cm layer and analyzed by the Soil Fertility Laboratory at UFERSA, presenting the following results shown in Table 1 .

Table 1. Chemical analyses of the soils before the incorporation of the spontaneous species biomass $M$. aegyptia and $C$. procera in the first (Soil 1) and the second cropping year (Soil 2) in the experimental areas.

\begin{tabular}{|c|c|c|c|c|c|c|c|c|c|c|c|c|c|}
\hline \multicolumn{14}{|c|}{ Prior to incorporation of the spontaneous species } \\
\hline \multirow{2}{*}{$\begin{array}{l}\text { Soils of } \\
\text { cropping } \\
\text { areas }\end{array}$} & \multirow{2}{*}{$\begin{array}{c}\mathrm{N} \\
\mathrm{g} \mathrm{kg}^{-1}\end{array}$} & \multirow{2}{*}{$\begin{array}{c}\mathrm{pH} \\
\text { (water) }\end{array}$} & \multirow{2}{*}{$\begin{array}{c}\text { EC } \\
\text { ds } m^{-1}\end{array}$} & \multirow{2}{*}{$\begin{array}{c}\mathrm{OM} \\
\mathrm{g} \mathrm{kg}^{-1}\end{array}$} & \multirow{2}{*}{\multicolumn{3}{|c|}{$\mathrm{mg} \mathrm{dm}^{-3}$}} & $\mathrm{Ca}^{2+}$ & $\mathrm{Mg}^{2+}$ & $\mathrm{Cu}$ & $\mathrm{Fe}$ & $\mathrm{Mn}$ & $\mathrm{Zn}$ \\
\hline & & & & & & & & \multicolumn{2}{|c|}{$\mathrm{cmol}_{\mathrm{c}} \mathrm{dm}^{-3}$} & \multicolumn{4}{|c|}{$\mathrm{mg} \mathrm{dm}^{-3}$} \\
\hline Soil 1 & 0.35 & 8.10 & 0.24 & 4.97 & 22.8 & 64.7 & 32.7 & 3.28 & 0.78 & 0.10 & 1.91 & 11.67 & 2.63 \\
\hline Soil 2 & 0.28 & 7.10 & 0.10 & 5.27 & 22.0 & 69.5 & 26.7 & 2.70 & 0.50 & 0.24 & 2.10 & 12.17 & 5.27 \\
\hline
\end{tabular}

N: Nitrogen; pH: Hydrogenionic potential; EC: Electrical conductivity; OM: Organic matter; P: Phosphorus; $\mathrm{K}^{+}$: Potassium; Na ${ }^{+}$: Sodium; $\mathrm{Ca}^{2+}$ : Calcium; $\mathrm{Mg}^{2+}$ : Magnesium; Cu: Copper; Fe: Iron; Mn: Manganese, and Zn: Zinc. Source: Authors 
The contents of the nutrients $\mathrm{N}, \mathrm{Na}, \mathrm{Ca}$ and $\mathrm{Mg}$ in Soil 1 were higher than those of soil 2, while the Zn content of Soil 2 was higher than that of Soil 1 (Table 1).

\subsection{Experimental procedure and treatments}

The experimental design used was randomized blocks, with treatments arranged in a 4 x 4 factorial scheme, with four replications. The first factor consisted of four equitable amounts of M. aegyptia and C. procera biomass mixture (20, 35, 50 and $\left.65 \mathrm{t} \mathrm{ha}^{-1}\right)$, and the second factor consisted of four population densities of arugula plants (400, 600, 800 and 1000 thousand plants $\left.\mathrm{ha}^{-1}\right)$, corresponding to $(40,60,80$ and 100\%) of the recommended density for single rocket (RDSC) cropping, intercropped with $100 \%$ of the radish RDSC. The recommended population densities for monocropping of radish and arugula in the region are 500 and 1000 thousand plants ha ${ }^{-1}$, respectively (Pereira et al., 2016; Lima et al., 2014). Single plots of radish and arugula crops were planted in each block to obtain agronomic and competition indices and economic indicators. These plots were fertilized with biomass equitable amounts of 44 and $40 \mathrm{t} \mathrm{ha}^{-1}$ of $M$. aegyptia and C. procera, optimized by the research in the region for the crops of radish and arugula.

The intercropped cultivation was established in alternating strips of the crops in the proportion of $50 \%$ of the area for the radish and $50 \%$ of the area for the arugula. Each plot consisted of four rows of radish alternating with four rows of arugula, flanked by two rows of each crop used as borders (Figure 2). The total area of the plot was $2.88 \mathrm{~m}^{2}$ and the harvest area of $1.60 \mathrm{~m}^{2}$ (consisting of the two central strips of plants, excluding the first and last plants of each line of the strips, used as a border).

Figure 2. Representation of the radish cultivation in the population density of 500 thousand plants ha ${ }^{-1}$ intercropped with the arugula in the population densities of 1000 (A), 800 (B), 600 (C) and 400 (D) thousand plants ha ${ }^{-1}$.
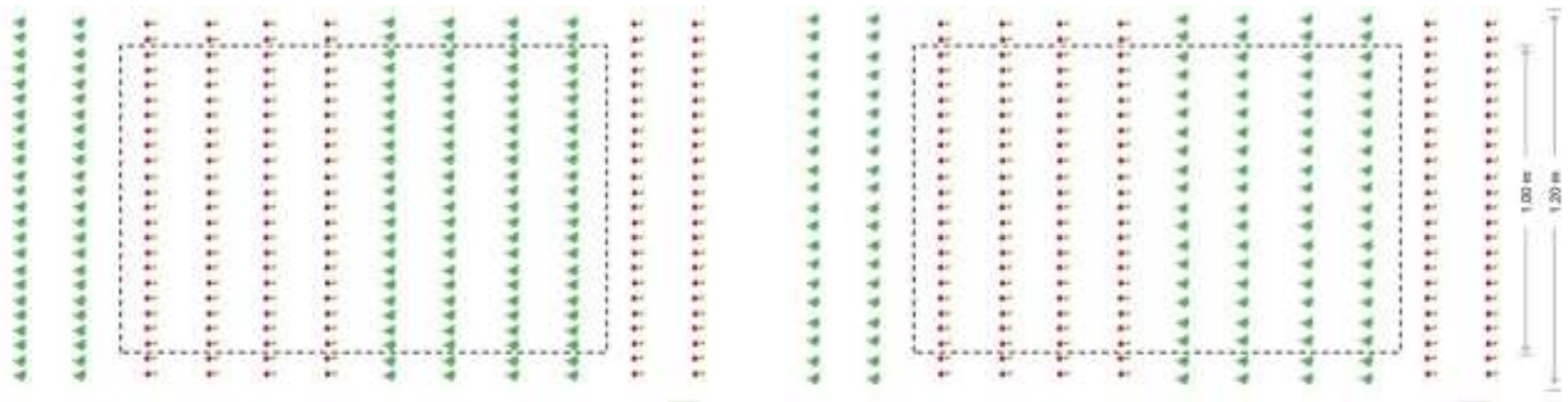

A
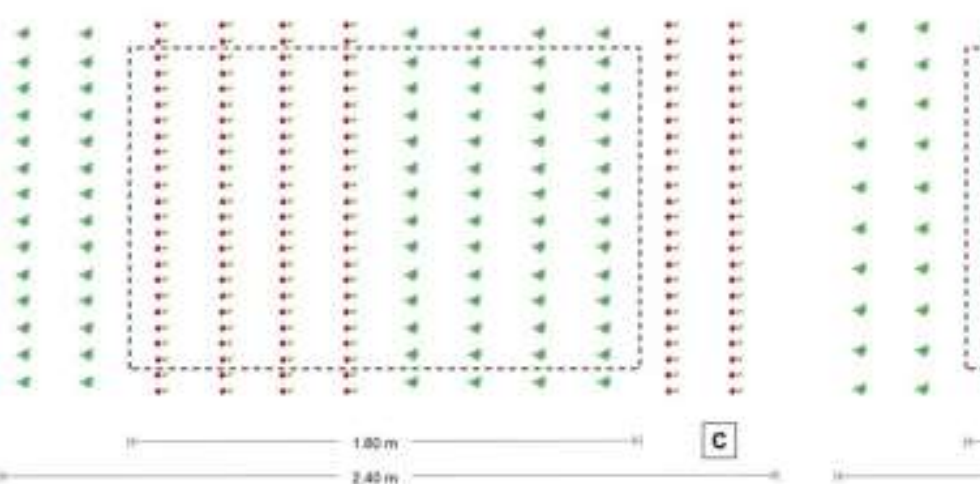

B

Source: Authors. 
In single crops, six rows per plot were planted in a total area of $1.44 \mathrm{~m}^{2}$ and harvest area of $0.80 \mathrm{~m}^{2}$, with a spacing of $0.20 \mathrm{~m} \times 0.10 \mathrm{~m}$ for the culture of radish and $0.20 \mathrm{~m} \times 0.05 \mathrm{~m}$ for arugula culture. The harvest area was made up of the four rows of central plants, excluding the first and last plants of each row, used as borders (Figure 3).

Figure 3. Representation of the single crops plots in the population densities of 500 (A) and 1000 (B) thousand plants per hectare for the radish and arugula crops.
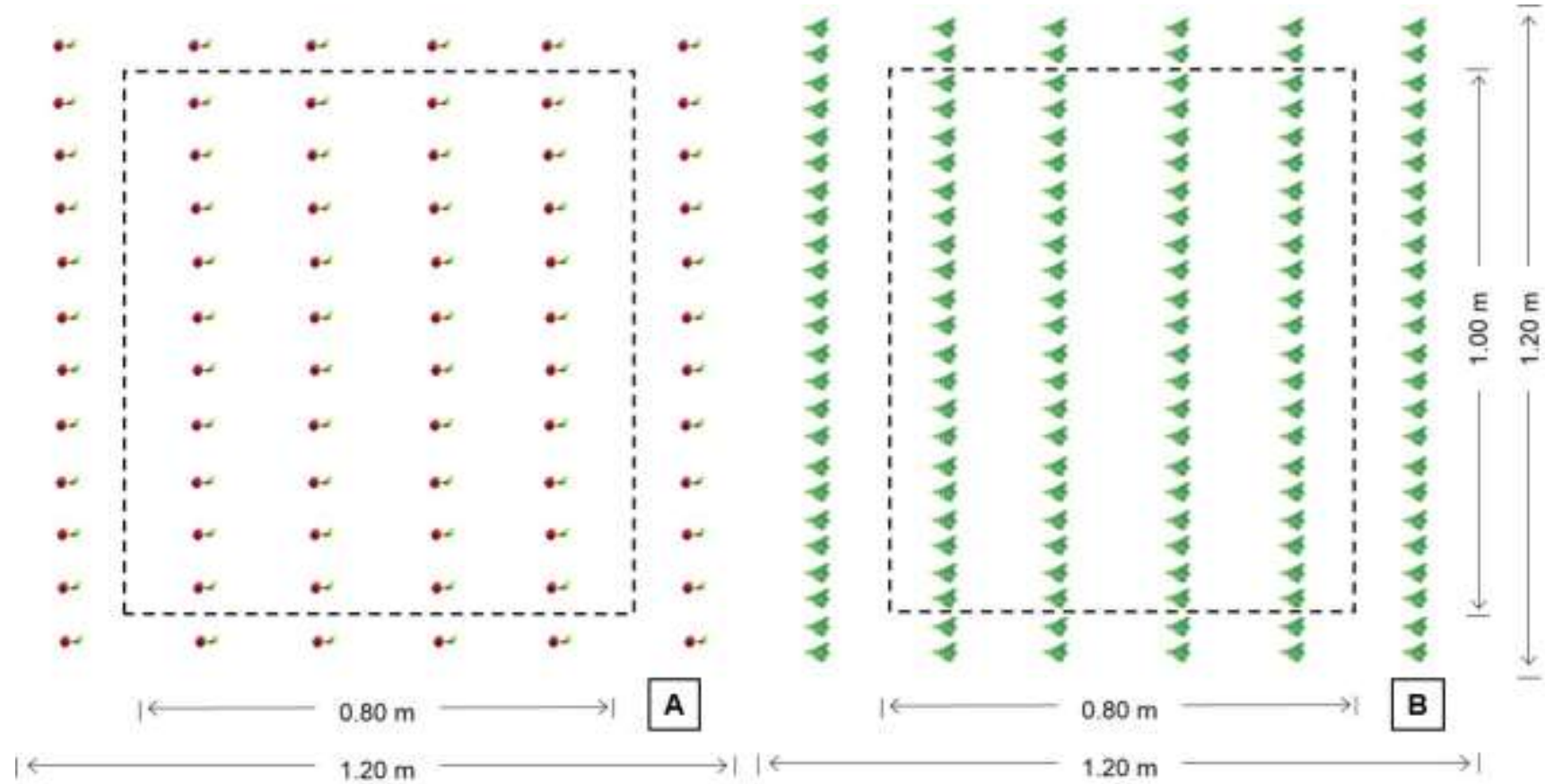

Source: Authors.

These monocultures are of paramount importance in the evaluation of the agro-economic efficiency indexes of the intercropped systems. The plant spacings of the radish and of arugula used in the intercropping and in the monocropping are shown in Table 2. 
Table 2. Description of the population densities of radish and arugula used in intercropping and in monocropping, with their respective spacings.

\begin{tabular}{|c|c|c|c|}
\hline \multicolumn{2}{|c|}{$\begin{array}{c}\text { Population densities of intercropped crops } \\
\text { (thousand plants } \text { ha-1) }^{-1} \text { ) }\end{array}$} & \multicolumn{2}{|c|}{ Spacings (m) } \\
\hline Radish & Arugula & $\begin{array}{c}\text { Radish } \\
\text { (1 plant per hole) }\end{array}$ & $\begin{array}{c}\text { Arugula } \\
\text { (2 plants per hole) }\end{array}$ \\
\hline 500 & $400 \quad$ (40\% RDSC) & $0.20 \times 0.05$ & $0.20 \times 0.120$ \\
\hline 500 & $600 \quad(60 \%$ RDSC $)$ & $0.20 \times 0.05$ & $0.20 \times 0.085$ \\
\hline 500 & $800 \quad$ (80\% RDSC) & $0.20 \times 0.05$ & $0.20 \times 0.062$ \\
\hline 500 & 1000 (100\% RDSC) & $0.20 \times 0.05$ & $0.20 \times 0.050$ \\
\hline \multicolumn{2}{|c|}{$\begin{array}{l}\text { Recommended population density for single crop - } \\
\text { RDSC (thousand plants } \mathrm{ha}^{-1} \text { ) }\end{array}$} & & (1 plant per hole) \\
\hline Radish & $500(100 \%$ RDSC $)$ & $0.20 \times 0.10$ & \\
\hline Arugula & 1000 (100\% RDSC) & & $0.20 \times 0.20$ \\
\hline
\end{tabular}

\subsection{Crop management and materials}

The preparation of the soil in the experimental area consisted of mechanical cleaning of the area with the aid of a tractor with a plow attached, followed by a harrowing and mechanized lifting of the beds. Subsequently, a pre-planting solarization was performed with transparent plastic like Vulca Brilho Bril Flex of 30 microns for 30 days in order to combat nematodes and phytopathogens in the soil.

The M. aegyptia and C. procera species were collected in a rural area located in the municipality of Mossoró-RN, and were then crushed in a conventional forage machine, obtaining fragmented particles around 2.0 to $3.0 \mathrm{~cm}$, dehydrated under sunlight for a period of 3 and 5 days for the M. aegyptia and C. procera, respectively, until the moisture content of 10\% is reached. A sample of the material was submitted to laboratory analyses providing the following results for these species shown in Table 3.

Table 3. Chemical analyses of macronutrients presents in the dry biomass of green manures M. aegyptia and C. procera in the first and second cropping year.

\begin{tabular}{lccccc}
\hline \multicolumn{1}{c}{ Green manures } & N & P & K & Mg & Ca \\
\hline \multirow{2}{*}{ M. aegyptia } & & - & \multicolumn{5}{c}{ Cropping year 2018 } \\
C. procera & 16.60 & 2.79 & 37.80 & 7.07 & 19.35 \\
& 21.90 & 1.92 & 20.90 & 9.22 & 17.00 \\
M. aegyptia & 15.30 & 4.00 & Cropping year 2019 & \\
C. procera & 18.40 & 3.10 & 25.70 & 7.03 & 9.30 \\
\hline
\end{tabular}

N: Nitrogen; P: Phosphorus; K: Potassium; Mg: Magnesium and Ca: Calcium; Mg. Source: Authors.

It can be seen in these results that the K content in 2018 was higher than in 2019.

The biomass amounts from the green manures were incorporated into the soil at 20 days before the sowing of the crops. The arugula and radish cultivars planted were 'Cultivada' and 'Crimson Gigante', respectively. 
The sowing of the crops was carried out on November 12, 2018 in the first cropping year, and on July 25, 2019 in the second cropping year, in holes approximately $3 \mathrm{~cm}$ deep, with three to four seeds per hole covered with commercial substrate. The thinnings of the arugula and radish were carried out by leaving two plants per hole for the arugula and one plant per hole for the radish in the intercropped system. In the single cropping, one plant was left per hole for both cultures.

The irrigations were performed by the micro sprinkler system, with a daily watering shift, divided into two applications (morning and afternoon), providing a water depth of approximately $8 \mathrm{~mm} \mathrm{day}^{-1}$.

During the conduction of the experiments, two manual weeding were carried out (with the weeds grubbing up) and a heap in the radish culture at 15 days after sowing (DAS). No chemical pest and disease control method was used.

The harvests of radish and arugula in the first cropping season were carried out at 29 and 30 days after sowing (DAS), and in the second growing season at 27 and 28 DAS, respectively, continuing with the evaluations.

\subsection{Measurements}

The variables evaluated in the intercropped systems were: commercial productivity of the radish roots, quantified by the fresh mass of the roots of the plants of the useful area, free of cracks and non-isoporized, expressed in $t \mathrm{ha}^{-1}$, and the green mass yield of the arugula plants, quantified by the fresh mass of plant shoots in the harvest area and expressed in $\mathrm{t} \mathrm{ha}^{-1}$.

The agro-economic efficiency of the combined systems of radish and arugula was determined using the following agronomic and competition indices, and economic indicators:

The land equivalent ratio (LER) was obtained by the following expression (Diniz et al., 2017): $L E R=Y_{r a} / Y_{r}+Y_{a r} / Y_{a}$, where $\mathrm{Y}_{\mathrm{ra}}$ is the productivity of commercial roots of the radish intercropped with the arugula; $\mathrm{Y}_{\mathrm{r}}$, the productivity of commercial radish roots in single cropping; $\mathrm{Y}_{\mathrm{ar}}$, the green mass yield of arugula intercropped with radish; $\mathrm{Y}_{\mathrm{a}}$, the green mass yield of arugula in single cropping.

The intercropping advantage (IA) was determined by the expression $(\mathrm{Gebru}, 2015): \mathrm{IA}=\mathrm{IA}_{\mathrm{r}}+\mathrm{IA}_{\mathrm{a}}$, where $\mathrm{IA}_{\mathrm{r}}=$ advantage of the intercropping of radish with arugula; $I_{A}=$ Advantage of the intercropping of arugula with radish; $I_{r}=A Y L_{r}$ $\times \operatorname{Pr}$ and $\mathrm{IA}_{\mathrm{a}}=A \mathrm{AL}_{\mathrm{a}} \times \mathrm{Pa}$, where $A Y L_{r}$ and $A Y L_{a}$ are defined in the description of the actual yield loss (AYL). Pr is the price of radish in $\mathrm{R} \$ \mathrm{~kg}^{-1}$ and $\mathrm{Pa}$ is the price of arugula in $\mathrm{R} \$ \mathrm{~kg}^{-1}$. The average prices paid to the producer in October 2018 and August 2019 were $\mathrm{R} \$ 4.08 \mathrm{~kg}^{-1}$ and $\mathrm{R} \$ 3.78 \mathrm{~kg}^{-1}$ for radish and arugula, respectively.

The actual yield loss (AYL) was obtained by the following expression (Cecilio Filho et al., 2015): AYL $=A Y L_{r}+$ $\mathrm{AYL}_{\mathrm{a}} ; \mathrm{AYL}_{\mathrm{r}}=\left[\left\{\left(\mathrm{Y}_{\mathrm{ra}} / \mathrm{Z}_{\mathrm{ra}}\right) /\left(\mathrm{Y}_{\mathrm{r}} / \mathrm{Z}_{\mathrm{r}}\right)\right\}-1\right]$ and $\mathrm{AYL} \mathrm{L}_{\mathrm{a}}=\left\{\left[\left(\mathrm{Y}_{\mathrm{ar}} / \mathrm{Z}_{\mathrm{ar}}\right) /\left(\mathrm{Y}_{\mathrm{a}} / \mathrm{Z}_{\mathrm{a}}\right)\right]-1\right\}$, where $\mathrm{AYL}$ is the actual yield loss of the system, $A Y L_{r}$ is the actual yield loss of the radish, AYL $L_{a}$ is the actual yield loss of the arugula, $Y_{r a}$ is the productivity of commercial roots of the radish in intercropping with arugula, $\mathrm{Z}_{\mathrm{ra}}$ is the planting proportion of the radish in the intercropping with the arugula, $Y_{r}$ is the productivity of commercial radish roots in single cropping, $Z_{r}$ is the planting proportion of the radish in single cropping, $\mathrm{Y}_{\mathrm{ar}}$ is the green mass yield of arugula intercropped with radish, $\mathrm{Z}_{\mathrm{ar}}$ is the planting proportion of arugula intercropped with radish, $\mathrm{Y}_{\mathrm{a}}$ is the green mass yield of the arugula in single cropping, and $\mathrm{Z}_{\mathrm{a}}$ is the planting proportion of the arugula in single cropping. If $\mathrm{AYL}>0$, this indicates accumulated advantage of the intercropping in relation to monocropping, if $A Y L<0$, this indicates disadvantage of the intercropping system.

The productive efficiency index (IEP) for each treatment was calculated using the DEA model with constant returns to scale (Mello \& Gomes, 2013), since there are no significant scale differences. This model has the mathematical formulation in which Xik is the value of input $i(i=1, \ldots, s)$, for the treatment $k(k=1, \ldots, n), Y j k$ is the value of output $j(j=1, \ldots, r)$, for the treatment $\mathrm{k}$, and vi and uj are the weights assigned to inputs and production, respectively; $\mathrm{O}$ is the treatment under analysis. 
$\operatorname{Max} \sum_{i=1}^{r} v_{i} x_{i \circ}$

$\sum_{j=1}^{s} u_{j} y_{j o}=1$

$\sum_{j=1}^{s} u_{j} y_{j k}, \sum_{i=1}^{r} v_{i} x_{i k} \leq 0, \mathrm{k}=1, \ldots, \mathrm{n} \quad \mathrm{u}_{\mathrm{j}}, \mathrm{v}_{\mathrm{i}} \geq \mathrm{o}, \mathrm{i}=1, \ldots, \mathrm{s}, \mathrm{j}=1, \ldots, \mathrm{r}$

The evaluation units were the treatments (intercrops), in a total of sixteen. As outputs, the commercial productivity of radish roots and the green mass yield of the arugula were used. To evaluate the yields of each plot, a single resource with a unitary level was considered, since the outputs incorporated the possible inputs. This model is equivalent to the additive multicriteria model, with the particularity that the alternatives themselves assign weights to each criterion, ignoring any opinion of any decision maker. In other words, DEA is used as a multicriteria tool and not as a measure of classical efficiency. In modeling this study, the profit margin was used as an input.

The efficiency of the intercropped system was also evaluated by the canonical variable score - Z (Silva et al., 2021), obtained through the bivariate analysis of the variance of the commercial productivity of radish roots and the green mass yield of the arugula.

The competition indexes of both cultures and the intercropping system were evaluated by the expressions used by Cecílio Filho et al. (2015) and Cecílio Filho et al. (2013). The aggressiveness (A) was determined by the expression: $\mathrm{A}_{\mathrm{ra}}=$ $\left[\mathrm{Y}_{\mathrm{ra}} /\left(\mathrm{Y}_{\mathrm{rr}} \times \mathrm{Z}_{\mathrm{ra}}\right)\right] \times\left(\mathrm{Z}_{\mathrm{ar}} / \mathrm{Z}_{\mathrm{ra}}\right)$ and $\mathrm{A}_{\mathrm{ar}}=\left[\mathrm{Y}_{\mathrm{ar}} /\left(\mathrm{Y}_{\mathrm{aa}} \times \mathrm{Z}_{\mathrm{ar}}\right)-\mathrm{Yra} /\left(\mathrm{Y}_{\mathrm{rr}} \times \mathrm{Z}_{\mathrm{ra}}\right)\right]\left(\mathrm{Z}_{\mathrm{ar}} / \mathrm{Z}_{\mathrm{ra}}\right)$, where $\mathrm{A}_{\mathrm{ra}}$ is the aggressiveness of the radish in the intercropping with the arugula, $A_{a r}$ is the aggressiveness of the arugula in the intercropping with the radish, $Y_{r a}$ is the commercial productivity of radish roots intercropped with the arugula; $Y_{a r}$ is the yield of the arugula intercropped with the radish, $\mathrm{Y}_{\mathrm{rr}}$ is the commercial productivity of the radish in monocropping, $\mathrm{Y}_{\mathrm{aa}}$ is the yield of the arugula in monocropping, $\mathrm{Z}_{\mathrm{ra}}$ is the planting proportion of the radish in intercropping with the arugula and $Z_{\mathrm{ar}}$ is the planting proportion of the arugula in intercropping with the radish. When $\mathrm{A}_{\mathrm{ra}}$ is greater than zero, the ability of the radish culture in terms of competition surpasses the ability of the arugula in the intercropping, or vice versa.

The competitive ratio of the radish $\left(\mathrm{CR}_{\mathrm{r}}\right)$ and arugula $\left(\mathrm{CR}_{\mathrm{a}}\right)$ was calculated by the following expressions: $\mathrm{CR}_{\mathrm{r}}=$ $\left[\left(\mathrm{Y}_{\mathrm{ra}} / \mathrm{Y}_{\mathrm{rr}}\right) /\left(\mathrm{Y}_{\mathrm{ar}} / \mathrm{Y}_{\mathrm{aa}}\right)\right] \times\left(\mathrm{Z}_{\mathrm{ar}} / \mathrm{Zra}\right)$ and $\mathrm{CR}_{\mathrm{a}}=\left[\left(\mathrm{Y}_{\mathrm{ar}} / \mathrm{Y}_{\mathrm{aa}}\right) /\left(\mathrm{Y}_{\mathrm{ra}} / \mathrm{Y}_{\mathrm{rr}}\right)\right] \times\left(\mathrm{Z}_{\mathrm{ra}} / \mathrm{Z}_{\mathrm{ar}}\right) . \mathrm{Y}_{\mathrm{a}}, \mathrm{Y}_{\mathrm{r}}, \mathrm{Y}_{\mathrm{ra}}, \mathrm{Y}_{\mathrm{ar}}, \mathrm{Z}_{\mathrm{ar}}$ and $\mathrm{Z}_{\mathrm{ra}}$ are defined in the description of aggressiveness (A).

Gross income (GI) was determined using the product of commercial productivity per hectare at the price paid to the producer at the market level in the region, in the months of October 2018 and August 2019. For the radish the price paid was $\mathrm{R} \$ 4.08 \mathrm{~kg}^{-1}$ and for arugula it was $\mathrm{R} \$ 3.78 \mathrm{~kg}^{-1}$.

Total costs were determined and verified at the end of the production cycle in October 2018 and August 2019, proceeding with an ex-post cost analysis (Silva et al., 2015). The cost modality analyzed in this research represents the total expenses (total costs) per hectare of cultivated area, which includes services provided by stable capital, that is, the contribution of working capital and the value of alternative costs (also called costs of opportunity).

Net income (NI) was calculated by subtracting total production costs (TC) from gross income (GI) per hectare.

The rate of return (RR) was expressed by the relationship between gross income (GI) and total costs (TC), that is, RR $=\mathrm{GI} / \mathrm{TC}$, corresponding to how many reals are obtained for each real invested in the intercropping of radish and arugula as a function of the treatments applied. The profit margin (PM) was obtained by the relationship between net income (NI) and gross income (GI), expressed as a percentage, according to the methodology used by Silva et al. (2017). 


\subsection{Statistical analysis}

Univariate analysis of variance for the randomized block design in a factorial scheme was used to evaluate the indices and indicators determined in the intercropped systems of radish and arugula, using the SISVAR software (Ferreira, 2011). Due to the homogeneity of the variances between the cropping years, an average of those years was made and a regression analysis was performed on these indexes and indicators. A procedure for adjusting regression curves using the Table Curve 3D software (Systat Software, 2002) was used to estimate the behavior of each index or indicator as a function of the equitable amounts of M. aegyptia and C. procera biomass and the population densities of the arugula studied.

\subsection{Quantitative and economic evaluation of benefits in intercropping systems}

In intercropped production systems for vegetables, it is common to involve capital, qualified labor and knowledge, the need to produce cheaper, with high quality and constancy, to maximize yields per unit of land area, food security, need satisfactory diet, among others, in addition to the availability of analytical tools and the ability to use them properly (Bezerra Neto et al., 2010; Bezerra Neto et al., 2012). This segment involves different sectors of the production chain such as organic, infrastructure and trade, and must be managed with competence to have the results properly evaluated and produce with reduced economic and environmental costs (Fontes, 2005).

Various indexes have been used both in the evaluation of the competition of the crops and in the agro-economic advantages of the intercropped systems (Gebru, 2015; Cecilio Filho et al., 2015). In the evaluation of agronomic advantages has been used, the LER, IA, AYL, PEI assessed using DEA (Data Envelopment Analysis) models, the canonical variable score (Z) obtained through bivariate analysis of productivity variance (Diniz et al., 2017; Gebru, 2015; Cecilio Filho et al., 2015; Mello \& Gomes, 2013; Silva et al., 2021) and the competition indices aggressivity (A) of the crops and CR of the system (Cecílio Filho et al., 2013). The LER is the most used by the researchers in the intercropping area. This index indicates the biological efficiency of the intercropping for using the resources of the environment in comparison with the single cropping (Mead \& Willey, 1980). The use of this index has some advantages, such as the one that can be used as a biological efficiency index to evaluate the effects of several agronomic variables such as levels of fertilization, spacing and population densities, cultivars, planting times and different cultures, etc., in the intercropped systems in one location or as a productivity index to compare a variety of intercropped systems in multiple locations (Chetty \& Reddy, 1984). The LER offers a basis for standardization compared to single crops, so that, the resources of the cultures can be added to form the combined ones (Mead \& Willey, 1980). When the LER is larger than one, the intercropping favors the growth and production of the component crops. In contrast, when the UET is less than one, the intercropping negatively affects the growth and production of the crops grown in the association (Caballero et al., 1995).

According to Jagannath and Sunderaraj (1987), in any comparison of benefits between intercropping systems with different land occupation areas, the intercropping's advantage via LER comes from two different sources that are generally confused: a) the land factor (area occupied by each component crop) and b) the biological/agronomic factor (of the tested factors/treatments).

It should be avoided to confirm the advantage in the intercropping of cultures only in values of a single index.

AYL is an index that provides more accurate information about competition in relation to other indexes between and within component crops and with respect to the behavior of each species in the intercropped system, because it is based on yield per plant (Banik et al., 2000). Thus, AYL represents loss or gain of intercrops in comparison with the respective single cultures, since it takes into account the actual sown proportion of the component cultures in relation to the single cultures. Positive or negative AYL values indicate the intercropping's advantage or disadvantage, that is, give a quantitative assessment of the accumulated advantage/disadvantage in any intercropping situation when the main objective is to compare the yield on a 
per plant basis. The magnitudes of the partial AYLs of the component cultures in intercropping reflect the nature of competition between and within the component cultures. AI is another indicator that expresses AYL in monetary terms and indicates the advantage of an intercropping system over another (Banik et al., 2000).

The PEI is also an index that aims to calculate the efficiency of productive units (treatments), using the DEA model with constant returns to scale (Cooper et al., 2004). The highest scores have the highest productive efficiencies. On the other hand, the bivariate analysis of variance performed on crop yields produces a $\mathrm{Z}$ score for each treatment tested, as it takes into account the correlations between the yields of the component crops, in addition to the higher discriminatory capacity and the description of relative superiority of treatments through the "yield of the intercropping", which simultaneously takes into account the yields of the component cultures involved in the experiment (Cruz et al., 1991). This index is very important in the evaluation of an intercropping, as it analyzes the yields of the cultures together, portraying the true situation or condition of a given treatment in the intercropped system in comparison to the others.

Indexes A and CR represent a measure of the competitive relationship between two cultures in intercropping (Willey, 1979). They are indices used to indicate how much the relative increase in the production of a component $\boldsymbol{c}$ culture is greater than that of component $\boldsymbol{a}$ in an intercropping system. If A is positive, then the component culture with a positive sign is the dominant and the one with a negative sign is the dominated. As this index is based on a simple difference, the interpretation of intercropped treatments can become difficult if the values are identical in different treatments. However, the two component cultures would be equally competitive. The greater the value of A (+ or -) the greater the difference in competitive capacity between species. The $\mathrm{CR}$ is an alternative index for assessing competition between different cultures and provides a better measure of the competitive capacity of component cultures. That is, CR provides the exact degree of competition by indicating the number of times that the dominant species is more competitive than the dominated species (Eskandari \& Ghanbari, 2010; Egbe et al., 2010). In an intercropping system, the culture with the highest CR makes better use of environmental resources.

The indicators of gross income, net income, rate of return and profit margin have been used to assess the economic advantages of intercropped systems (Silva et al., 2017; Andrade Filho et al., 2020; Silva et al., 2015). GI refers to the value of the combined crop production involved in the intercropping system, without concern for the product's production costs involving inputs and services (Feiden, 2001). NI, on the other hand, takes into account the production costs, that is, the prices of inputs and services in force during the system's cultivation period are used. According to Beltrão et al. (1984), this economic indicator is more real to assess the intercropped agrosystem than the GI, because the system's production costs are not included in it.

The costs of production of an intercropping system, according to Cecílio Filho et al. (2010) are obtained through the total expenses (total cost) per hectare with the component crops of the system at the experimental level, which covers the services provided by the stable capital (depreciation, opportunity or alternative costs, fixed labor and costs associated with working capital) and the value of alternative costs (also called opportunity costs).

The RR is an index that represents how many reals are obtained from profit for each real invested and the PM is an indicator that expresses the percentage of the profit obtained from the total value of the production of an intercropping system. Anyway, an important question for those practicing the intercropped systems is to know if the values obtained with the agronomic and competition indexes have been translated into economic terms, and thus allow the producer the option of using the intercropping practice as a viable technology for agricultural production. 


\section{Results and Discussion}

\subsection{Agronomic indexes}

Significant interaction between treatment-factors, equitable amounts of $M$. aegyptia and $C$. procera biomass incorporated into the soil and arugula population densities was recorded for the intercropping advantage (IA), and no significant interaction was observed for land equivalent ratio (LER), actual yield loss (AYL), productive efficiency index (PEI), and for the score of the canonical variable - Z (Table 4).

Table 4. F values for land equivalent ratio (LER), intercropping advantage (IA), actual yield loss (AYL), productive efficiency index (PEI), and score of canonical variable (Z), of radish intercropped with arugula as a function of different amounts of $M$. aegyptia and C. procera biomass and population densities of arugula.

\begin{tabular}{lcccccc}
\hline \multicolumn{1}{c}{ Sources of variation } & DF & LER & IA & AYL & PEI & Z \\
\hline Blocks & 3 & $5.30^{* *}$ & $6.85^{* *}$ & $8.22^{* *}$ & $4.52^{* *}$ & $5.24^{* *}$ \\
Amounts of $M$. aegyptia and & & & & & \\
C. procera biomass (A) & 3 & $16.33^{* *}$ & $23.90^{* *}$ & $18.81^{* *}$ & $1.99^{\mathrm{ns}}$ & $24.62^{* *}$ \\
Population densities of arugula (D) & 3 & $19.05^{* *}$ & $33.18^{* *}$ & $25.05^{* *}$ & $4.03^{*}$ & $21.02^{* *}$ \\
A x D & 9 & $1.39^{\mathrm{ns}}$ & $2.85^{* *}$ & $1.30^{\mathrm{ns}}$ & $0.90^{\mathrm{ns}}$ & $1.61^{\mathrm{ns}}$ \\
\hline CV $(\%)$ & & 9.24 & 24.13 & 31.85 & 9.26 & 13.90 \\
\hline
\end{tabular}

** $=\mathrm{P}<0.01 ; *=\mathrm{P}<0.05 ; \mathrm{ns}=\mathrm{P}>0.05$. Source: Authors.

However, a response surface was adjusted for all these agronomic efficiency indices as a function of the treatmentfactors, where the maximum values of $1.64 ; 5.16 ; 1.31 ; 0.86$ and 1.54 were achieved by combining an biomass equitable amount from the $65 \mathrm{t} \mathrm{ha}^{-1}$ of the green manures and a population density of $100 \%$ of the RDSC of the arugula, corresponding to 1000 thousand plants per hectare (Figure 4). 
Figure 4. Land equivalent ratio (A), intercropping advantage (B), actual yield loss (C), productive efficiency index (D), and score of the canonical variable $\mathrm{Z}$ (D) of the radish and arugula intercropping as a function of equitable amounts of M. aegyptia and $C$. procera biomass incorporated into the soil and of arugula population densities.

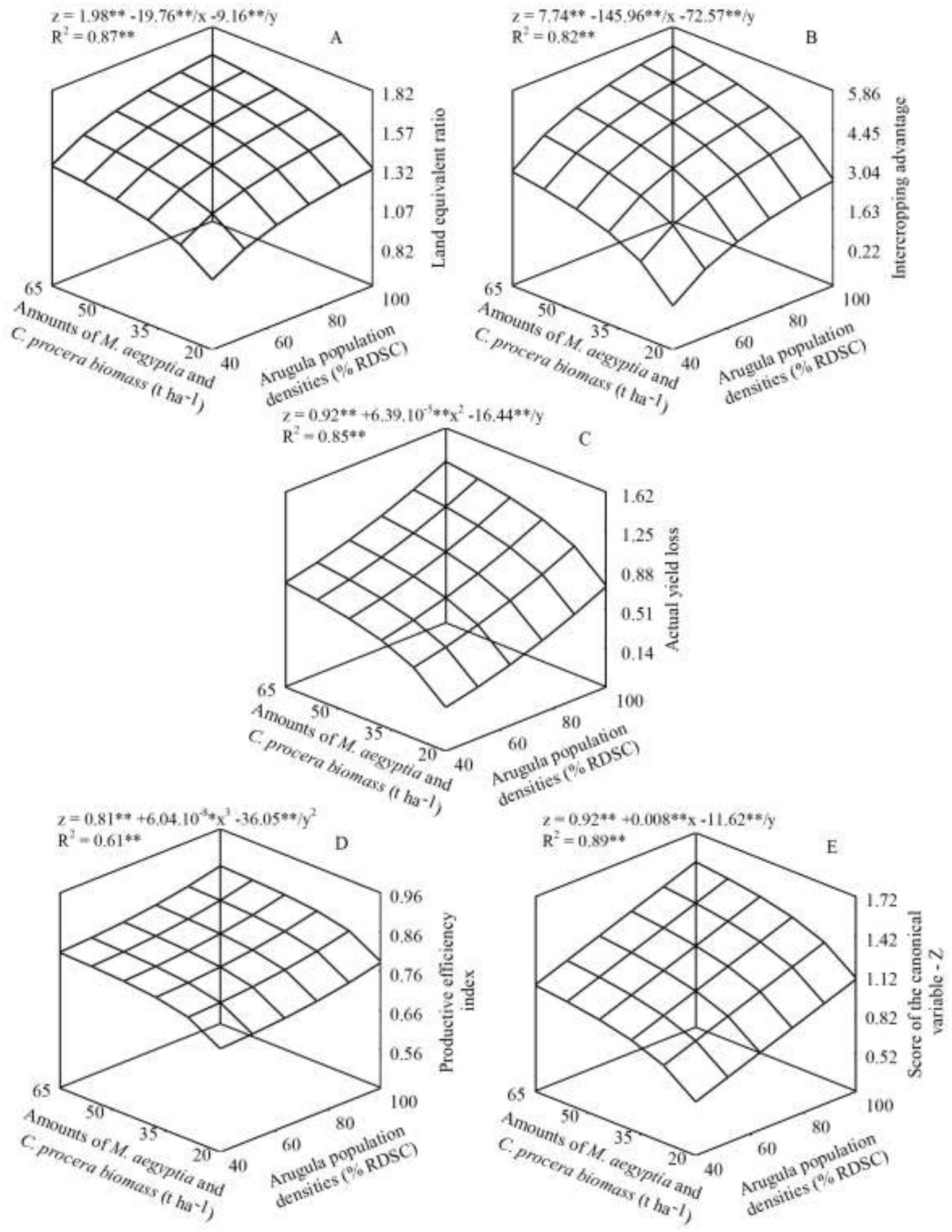

Source: Authors.

These results indicate that there was a maximization in the use of environmental resources, due to improvements in the physical, chemical and biological characteristics of the soil due to the incorporation of green fertilizers, thus reflecting in 
greater agronomic efficiency of the intercropped system. It is known that green manuring, in addition to improving fertility, increases organic matter content, decreases erosion rates, favors soil water retention, increases soil microbiota activity, increasing nutrient availability and reducing number of invasive plants (Graham \& Haynes, 2006).

On the other hand, morphophysiological and treatment-factor differences such as population density, proportion of crops in intercropping and application of fertilizers regulate competition between component crops for growth limiting factors (Morgado \& Willey, 2008). Therefore, in view of this, the greater total absorption of nutrients and an increase in the population density of component crops in intercropping is the main cause of obtaining an advantage in the intercropping.

This intercropping advantage can be seen in the LER and AYL values. The LER > 1 is an indicator of the system's superiority in the use of environmental resources when compared to single cropping (Oseni, 2010). Thus, it can be inferred that, in this study, there was a progressive increase in the use of environmental resources with the increase in the amount of green fertilizers and the density of arugula plants in the area, represented by the increasing values of LER greater than 1 . In addition, the increase in the total number of plants in the area positively affected the interspecific relationships of the component crops, resulting in a more advantageous system in relation to single cropping, expressed by the value of AYL > 1 . It is important to note that the value of AYL gives more information precise intra and interspecific competition between species in the intercropped system (Dhima et al., 2007).

Oliveira et al. (2017), studying the tuberose (carrot) polycultures with broadleaves, such as arugula and lettuce under green manure with increasing amounts of $C$. procera in different proportions of population densities of the component crops, obtained higher rates of agronomic efficiency for LER (1.96), PEI (0.85) and Z (1.34) as a function of the greater amount of green manure incorporated into the soil and the higher proportion of tested population densities. These values of these indices obtained in this polyculture were close to those obtained in the research in focus, thus showing, as the combination, amounts of fertilizer applied and population densities of the tested component crops, is of paramount importance in the use of environmental resources, consequently translating into an advantage in the practice of intercropping of tubers with hardwoods.

\subsection{Competition indexes}

Significant interaction between the treatment-factors, equitable amounts of M. aegyptia and C. procera biomass incorporated into the soil and arugula population densities was recorded in the aggressivity of radish $\left(A_{r}\right)$ and arugula $\left(A_{a}\right)$ crops, as well as in competitive ratio (CR) of the intercropped system (Table 5).

Table 5. F values for aggressivity of the radish $\left(A_{r}\right)$, aggressivity of the arugula $\left(A_{a}\right)$ and competitive ratio of the radish and arugula intercropping $(\mathrm{CR})$ as a function of equitable amounts of $M$. aegyptia and $C$. procera biomass incorporated into the soil and of arugula population densities.

\begin{tabular}{lcccc}
\hline \multicolumn{1}{c}{ Sources of variation } & $\mathrm{GL}$ & $\mathrm{A}_{\mathrm{r}}$ & $\mathrm{A}_{\mathrm{a}}$ & $\mathrm{CR}$ \\
\hline Blocks & 3 & $1.96^{\mathrm{ns}}$ & $1.96^{\mathrm{ns}}$ & $1.21^{\mathrm{ns}}$ \\
Amounts of $M$. aegyptia and & 3 & $17.96^{* *}$ & $17.96^{* *}$ & $29.55^{* *}$ \\
C. procera biomass (A) & & $3.70^{*}$ & $3.70^{*}$ & $11.41^{* *}$ \\
$\begin{array}{l}\text { Population densities of arugula (D) } \\
\text { A x D }\end{array}$ & 3 & $3.20^{* *}$ & $3.20^{* *}$ & $4.09^{* *}$ \\
\hline $\mathrm{CV}(\%)$ & 9 & 42.44 & -42.44 & 6.22 \\
\hline
\end{tabular}

$$
* *=\mathrm{P}<0.01 ; *=\mathrm{P}<0.05 ; \mathrm{ns}=\mathrm{P}>0.05 . \text { Source: Authors. }
$$

A response surface was adjusted for these competition indices as a function of the treatment-factors, where the maximum values of the radish aggressivity on the arugula and the competitive ratio of the intercropped system of 0.19 and 
2.75 were achieved in the combination of the equitable amount of the green manures biomass of $20 \mathrm{t} \mathrm{ha}^{-1}$ and population density of $40 \%$ of the RDSC of the arugula, and that of arugula aggressivity was -0.03 in the combination of the equitable amount of the green manures biomass of $65 \mathrm{t} \mathrm{ha}^{-1}$ and population density of $100 \%$ of the RDSC of the arugula (Figure 5).

Figure 5. Radish aggressivity (A), arugula aggressivity (B) and competitive ratio (C) of the radish and arugula intercropping as a function of equitable amounts of M. aegyptia and C. procera biomass incorporated into the soil and arugula population densities.
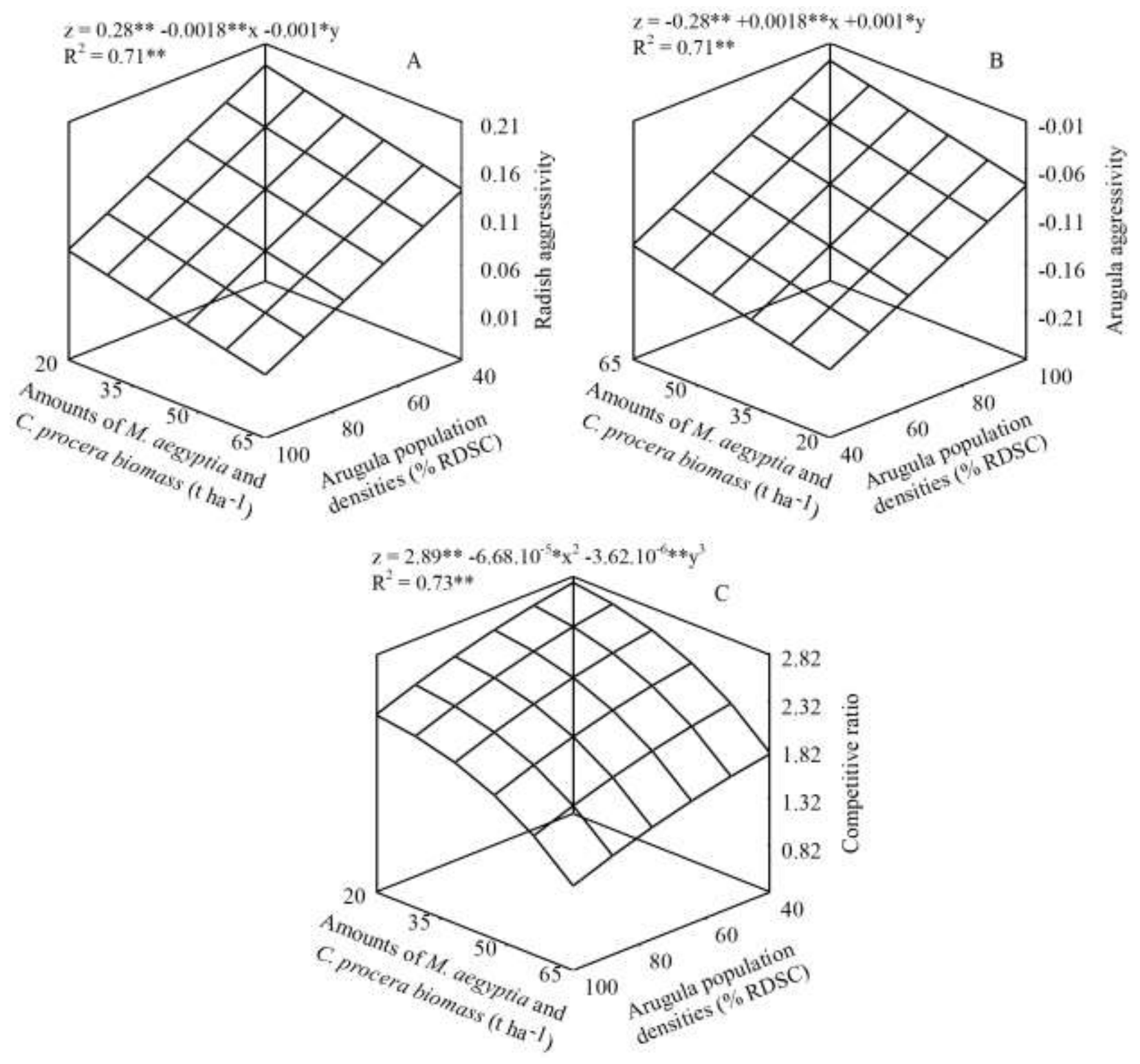

Source: Authors.

In the present study, the aggressiveness indices (A) of the crops and the competitive ratio (CR) were used to quantify the beneficial competitive effects in different planting patterns of radish and arugula, since they facilitate the description of the competitive behavior of the intercropped system. They have been used to assess competition in the radish and rocket intercropping, where the broadleaves population varied in different density patterns, amounts of green manures and cropping years. Competition is one of the main factors that significantly impact the growth rate and productivity of the crops used in the intercropping when compared to monocultures. 
The positive values of the radish's aggressivity on the arugula indicates that this tuberose was the dominant crop in the system and more competitive as the arugula density is reduced. The negative values of the arugula's aggressivity on the radish indicates that this broadleaf was the dominated crop. This result also indicates that the arugula has less interspecific competition capacity when compared to the radish, regardless of the number of plants in the area. In general, plant density and the relative proportion of component crops are important to determine the efficiency of intercropped systems. According to Willey and Osiru (1972) when the proportion of the component crops is approximately equal, efficiency and productivity seem to be determined by the most aggressive crop in the system.

Regarding competitive relations, the maximum points found in the respective amounts of green manures and population densities, represent the use of environmental resources, such as water, sunlight and nutrients with maximum efficiency (Nunes, et al., 2018). The maximum point obtained in these indices expresses the exact degree of competitiveness between species by indicating the number of times that the dominant species was more competitive than the dominated species.

The decreasing values of $\mathrm{CR}$ observed with the increasing incorporation of vegetable biomass and with the increasing population densities of arugula indicate a reduction in the degree of competition between species and thus provide an increase in the efficiency of the intercropping, as a function of the better use of environmental resources. This effect can be attributed to the aggressivity of the dominant species, the radish, and to factors related to the morphology, physiology and nutritional needs of plants. According to (Zang et al., 2015), difference in the architecture of plants, especially roots, determines how they access and use soil nutrients. Thus, it can be inferred that the reduction in the competition ratio of the radish and arugula intercropping may be related to the complementarity between the component cultures as a function of the differences in the architecture of these cultures and in the way they use natural resources. According to Passos et al. (2019), the competitiveness of a crop is proportional to the increase in plant density in the studied area. Thus, with the increase in the arugula population densities and an increase in the amounts of green manures, it was found that the competitive ability of the arugula decreased and that of the radish increased.

\subsection{Economic indicators}

Significant interaction between treatment-factors, equitable amounts of $M$. aegyptia and C. procera biomass incorporated into the soil and arugula population densities was recorded for net income (NI). On the other hand, no significant interaction was recorded for the indicators gross income (GI), rate of return (RR) and profit margin (PM), Table 6.

Table 6. F values for gross income (GI) net income (NI), rate of return (RR) and profit margin (PM) of radish intercropped with arugula as a function of different amounts of $M$. aegyptia and $C$. procera biomass and population densities of arugula.

\begin{tabular}{lccccc}
\hline \multicolumn{1}{c}{ Sources of variation } & GL & GI & NI & RR & PM \\
\hline Blocks & 3 & $5.68^{* *}$ & $3.89^{*}$ & $7.04^{* *}$ & $4.36^{* *}$ \\
Amounts of $M$. aegyptia and & 3 & $14.39^{* *}$ & $9.48^{* *}$ & $12.22^{* *}$ & $16.24^{* *}$ \\
C. procera biomass (A) & & & & \\
Population densities of arugula (D) & 3 & $20.47^{* *}$ & $10.80^{* *}$ & $3.94^{*}$ & $9.22^{* *}$ \\
A x D & 9 & $1.54^{\mathrm{ns}}$ & $2.56^{*}$ & $1.67^{\mathrm{ns}}$ & $1.90^{\mathrm{ns}}$ \\
\hline CV $(\%)$ & & 8.97 & 13.72 & 8.50 & 8.72 \\
\hline
\end{tabular}

$* *=\mathrm{P}<0.01 ; * \mathrm{P}<0.05 ; \mathrm{ns}=\mathrm{P}>0.05$. Source: Authors.

However, a response surface was adjusted for all these economic indicators as a function of the treatment-factors, with maximum values of $\mathrm{R} \$ 45,543.92$ and $\mathrm{R} \$ 24,662.31 \mathrm{ha}^{-1}$ for gross and net incomes, of $\mathrm{R} \$ 2,20$ for each real invested and 
$56.37 \%$ of profit margin achieved in the combination of equitable amount of green manures biomass of $65 \mathrm{t} \mathrm{ha}^{-1}$ and population density of $100 \%$ of the RDSC of the arugula, corresponding to 1000 thousand plants per hectare (Figure 6).

Figure 6. Gross income (A), net income (B), rate of return (C), and profit margin (D) of the radish and arugula intercropping as a function of equitable amounts of $M$. aegyptia and C. procera biomass incorporated into the soil and arugula population densities.
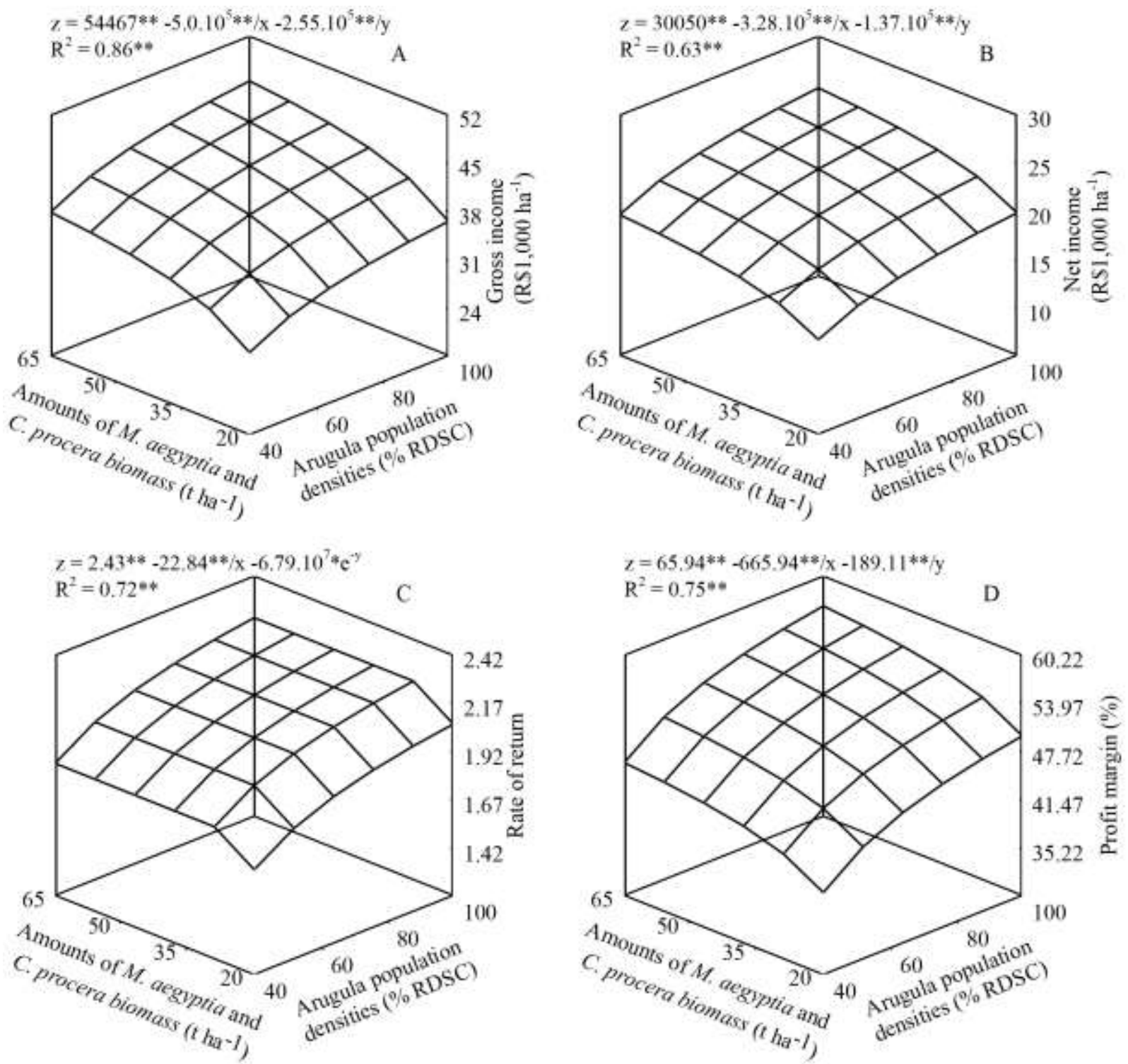

Source: Authors.

The results observed in these economic indicators, mainly the net income, express in monetary terms the agronomic /biological advantage obtained in the intercropping of radish with arugula as a function of the increase in the equitable amounts of the M. aegyptia and C. procera biomass incorporated in the soil and of the increase in the population densities of the arugula, expressed by the greater agronomic/biological efficiency in relation to single cropping, indicating that it is advantageous to combine radish with arugula organically, properly managing the population density of the arugula culture. Net income is an indicator that has the advantage of comparing not only the agronomic/biological efficiency of crop systems, but 
also takes into account the fact that inputs, especially labor, are limited and need to be used in different quantities for different cropping systems. It expresses in net terms the value of biological efficiency free of production costs.

It is known that the economic analysis complements the evaluation of the agronomic/biological efficiency of the intercropped systems, as it considers, in addition to the physical production of the crops, the price of the products according to their commercial classification, of quality and of growing time in the year. Gross income is an indicator that represents the value of crops combined yields in each intercropped system, regardless of production costs. It depends exactly on the price that the production of the system is marketed. The rate of return is another indicator that depends on production costs, since it is standardized in terms of those costs. The higher the values of these indicators, the greater the advantage of the intercropped system. In turn, the profit margin is another indicator standardized by net income, which expresses in percentage terms the agronomic/biological efficiency of the intercropped system. The higher the values of these indicators, the greater the net advantage of the system. Thus, the results obtained in the agronomic and competition indices agree with those obtained in the economic indicators evaluated in this study.

The maximum economic indicators obtained in this study $\left(\mathrm{GI}=\mathrm{R} \$ 45,543.92 \mathrm{ha}^{-1} ; \mathrm{NI}=\mathrm{R} \$ 24,662.31 \mathrm{ha}^{-1} ; \mathrm{RR}=\mathrm{R} \$\right.$ 2.20 for each real invested and $\mathrm{PM}=56.37 \%$ ) were higher than those obtained by Oliveira et al. (2017), where they cultivated arugula and lettuce in intercropping with carrot as a function of amounts of $C$. procera biomass in different population densities of leafy crops in the same growing region of this research, where they obtained the following results: GI $=$ RS 34,513.95 ha- ${ }^{-1}$ R $\$ 14,142.68 \mathrm{ha}^{-1} ; \mathrm{RR}=\mathrm{R} \$ 1.69$ for each real invested and PM = 39.39\%). This difference between two researches is due to the production costs of the tested treatments.

\section{Conclusion}

The greatest agroeconomic advantages of the radish-arugula intercropping were achieved with a land equivalent ratio (LER) of 1.64, productive efficiency index (PEI) of 0.86 , a score of the canonical variable (Z) of 1.54, gross income (GI) of R\$ $45,543.92 \mathrm{ha}^{-1}$, net income (NI) of R $\$ 24,662.31 \mathrm{ha}^{-1}$, rate of return (RR) of R 2.20 for each real invested and $56.37 \%$ profit margin, respectively, in the combination of $65 \mathrm{t} \mathrm{ha}^{-1}$ of M. aegyptia and C. procera biomass and arugula population density of 1000 thousand plants per hectare. Radish and arugula intercropping is feasible for agronomic and economic efficiency and sustainability. This cropping system should be recommended to family farmers who produce leafy and tuberous vegetable crops in a sustainable way in semi-arid environment. The LER, ATER, LUE, BEP, GI, NI, RR, CMA, CR and A indexes evaluated can assist the producer in making appropriate decisions in the implementation of his intercropping production system in terms of complementarity and sustainability. Radish behaved as a dominant crop, while arugula as a dominated crop. The use of biomass mixtures of M. aegyptia and C. procera from the Caatinga biome, proved to be a viable technology for producers who practice the cultivation of radish and arugula in strip intercropping in semiarid environment. Given the possibility of obtaining of high crop productivity and of high-quality products from intercropped systems of tuberous and broadleaves, there is an urgent need for research on the proper management of production factors such as: organic manuring, genotypes suitable for the intercropped system, types of intercrops regarding the spatial arrangement and population density of the component crops as well as the establishment of adequate planting times for the crops in the different ecosystems where they are implanted.

\section{Acknowledgments}

Special thanks are due to the National Council for Scientific and Technological Development (CNPq/Brazil), process $\mathrm{n}^{\mathrm{o}}$ 305222/2019-8 and to Coordination for the Improvement of Higher Education Personnel (CAPES/Brazil) - Finance Code 
001 for the financial support and to the group of research in the Agronomic and Forest Sciences Department at the Federal Rural University for the Semi-Arid, which develops technologies for growing crops on family farms.

\section{References}

Almeida, A. E. S., Bezerra Neto, F., Costa, L. R., Silva, M. L., Lima, J. S. S., \& Barros Júnior, A. P. (2015). Eficiência agronômica do consórcio alface-rúcula fertilizado com flor-de-seda. Revista Caatinga, 28(3), 79-85.

Alvares, C. A., Stape, J. L., Sentelhas, P. C., Gonçalves, J. L. de M., \& Sparovek, G. (2014). Koppen's climate classification map for Brazil. Meteorologische Zeitschrift, 22 (6), 711-728. 10.1127/0941- 2948/2013/0507

Andrade Filho, F. C., Oliveira, E. Q., Lima, J. S. S., Moreira, J. N., Silva, I. N., Lins, H. A., Cecílio Filho, A. B., Barros Junior, A. P., \& Bezerra Neto, F. (2020). Agro-economic viability from two croppings of broadleaf vegetables intercropped with beet fertilized with roostertree in different population densities. Revista de la Facultad de Ciencias Agrarias, 52 (1), 210-224.

Banik, P., Sasmal, T., Ghosal, P. K., \& Bagchi, D. K. (2000). Evaluation of mustard (Brassica compestris Var. Toria) and legume intercropping under 1:1 and 2:1 row-replacement series systems. Journal of Agronomy and Crop Science, 185(1), 9-14.

Batista, M. A. V., Bezerra Neto, F., Ambrósio, M. M. Q., Guimaraes, L. M. S., Saraiva, J. P. B., \& Silva, M. L. (2013). Atributos microbiológicos do solo e produtividade de rabanete influenciados pelo uso de espécies espontâneas. Horticultura Brasileira, 31(4), 587-594. 10.1590/S0102-0536201300 0400013.

Batista, T. M. V., Bezerra Neto, F., Porto, V. C. N., Barros Junior, A. P., Silva, I. N., Silva, M. L., Lima, J. S. S., \& Oliveira, E. Q. (2016). Bio-agro-economic returns from carrot and salad rocket as intercrops using hairy woodrose as green manure in a semi-arid region of Brazil. Ecological Indicators, 67(1), 458-465, 2016. 10.1016/j.ecolind.2016.03.018

Bezerra Neto, F., Gomes, E. G., Araújo, R. R. de, Oliveira, E. Q. de, Nunes, G. H. de S., Grangeiro, L. C., \& Azevedo, C. M. da S. B (2010). Evaluation of yield advantage indexes in carrot-lettuce intercropping systems. Interciencia, 35(1), 59-64.

Bezerra Neto, F., Porto, V. C. N., Gomes, E. G., Cecílio Filho, A. B., \& Moreira, J. N.(2012). Assessment of agroeconomic indices in polycultures of lettuce, rocket and carrot through uni- and multivariate approaches in semi-arid Brazil. Ecological Indicators, 14(1), 11-17. 10.1016/j.ecolind. 2011.07.006

Caballero, R., Goicoechea, E. L., \& Hermaiz, P. J. 1995. Forage yields and quality of common vetch and oat sown at varying seeding ratios and seeding rates of common vetch. Field Crops Research, 41(2), 135-140.

Cecílio Filho, A. B., Bezerra Neto, F., Rezende, B. L. A., Barros Júnior, A. P., \& Lima, J. S. S. (2015). Indices of bio-agroeconomic efficiency in intercropping systems of cucumber and lettuce in greenhouse. Australian Journal of Crop Science, 9(12), 1154-1164.

Cecílio Filho, A. B., Bezerra Neto, F., Rezende, B. L. A., Grangeiro, L. C., \& Lima, J. S. S. (2013). Indices of competition and bio-agroeconomic efficiency of lettuce and tomato intercrops in greenhouses. Australian Journal of Crop Science, 7(6), 809-819.

Cecílio Filho, A. B., Rezende, B. L. A., \& Costa, C. C. (2010). Economic analysis of the intercropping of lettuce and tomato in different seasons under protected cultivation. Horticultura Brasileira, 28(3), 326-336.

Chetty, C. R. K., \& Reddy, M. N. (1984). Analysis of intercrop experiments in dryland agriculture. Experimental Agriculture, 20(1), 31-40.

Cooper, W. W., Seiford, L. M., \& Zhu, J. (2004). Handbook on Data Envelopment Analysis. Boston: Kluwer Academic Publishers. 608p.

Cruz, C. D., Magalhães, P. C., \& Pereira Filho, I. A. (1991). Análise bivariada do rendimento de milho e feijão em sistema consorciado. Revista Ceres, 38(218): 332-339.

Dhima, K. V., Lithourgidis, A. S., Vasilakoglou, I. B., \& Dordas, C. A. (2007). Competition indices of common vetch and cereal intercrops in two seeding ratio. Field Crops Research, 100 (2/3), 249-256. 10.1016/j.fcr.2006.07.008

Diniz, W. J. S., Silva, T. G. F., Ferreira, J. M. S., Santos, D. C., Moura, M. S. B., Araújo, G. G. L., \& Zolnier, S. (2017). Forage cactus-sorghum intercropping at different irrigation water depths in the Brazilian semiarid region. Pesquisa Agropecuária Brasileira, 52(9), p.724-733. 10.1590/S0100-204X2017 000900004

Egbe, O. M., Alibo, S. E., \& Nwueze, I. (2010). Evaluation of some extra-early- and early-maturing cowpea varieties for intercropping with maize in southern Guinea Savanna of Nigeria. Agriculture and Biology Journal of North America, 5(1), 845-858.

Eskandari H, Ghanbari A (2010) Environmental resource consumption in wheat (Triticum aestivum) and bean (Vicia faba) intercropping: Comparison of nutrient uptake and light interception. Notulae Scientia Biologicae, 2(3), 100-103

Feiden, A. (2001). Metodologia para Análise Econômica em Sistemas Agroecológicos - $1^{a}$ Aproximação: Analise de Culturas Individuais. Seropédica: Embrapa Agrobiologia, 30p. (Embrapa Agrobiologia. Documentos, 141).

Ferreira, D. F. (2011). Sisvar: a computer statistical analysis system. Ciência e Agrotecnologia, 35 (6), 1039-1042. 10.1590/S1413-70542011000600001

Fontes, P.C.R., 2005. A produção de hortaliças - Olericultura. In: Fontes, P.C.R. (Ed.), Olericultura: teoria e prática. UFV. . 3-13.

Gebru, H. (2015). A review on the comparative advantages of intercropping to mono-cropping system. Journal of Biology, Agriculture and Healthcare, 5(9), $1-13$. 
Graham M. H., \& Haines R. J. (2006) Organic matter status and the size, activity and metabolic diversity of the soil microbial community in the row and interrow of sugar cane under burning a trash retention. Soil Biology \& Biochemistry, 38(1): 21-31. 10.1016/j.soilbio.2005.04.011

Hata, F. T., Ventura, M. U., Sousa, V., \& Fregonezi, G. A. F. (2019). Low-cost organic fertilizations and bioactivator for arugula-radish intercropping. Emirates Journal of Food and Agriculture, 31(10), 773-778. 10.9755/ejfa.2019.v31.i10.2018

Jagannath, M. K., \& Sunderaraj, N (1987). Productivity equivalent ratio and statistical testing of its advantage in intercropping. Journal of the Indian Society of Agricultural Statistics, 39(3), 289-300.

Lima, J. S. S. de, Bezerra Neto, F., Negreiros, M. Z. de, Freitas, K. K. C. de, \& Barros Júnior, A. P (2007). Desempenho agroeconômico de coentro em função de espaçamentos e em dois cultivos. Revista Ciência Agronômica, 38(4), p.407-413.

Lima, V. I. A. de, Lima, J. S. S. de, Bezerra Neto, F., Santos, E. C. dos, Rodrigues, G. S. de O., \& Paula, V. F. S. de. (2014). Viabilidade agroeconômica do cultivo consorciado de coentro, alface e rúcula sob diferentes arranjos espaciais. Enciclopédia Biosfera, 10(18), 3060-3065.

Mead, R., \& Willey, R. W. (1980). The concept of a Land Equivalent Ratio and advantages in yields from intercropping. Experimental Agriculture, $16(3), 217-228$.

Meira, A. L., Leite, C. D., \& Moreira, V. R. R. 2012. Plantas companheiras. São Paulo: Coordenação de Agroecologia - Ministério da Agricultura, Pecuária e Abastecimento.

Mello, J. C. C. B. S. de, \& Gomes, E. G. (2013). Eficiências aeroportuárias: Uma abordagem comparativa com análise de envoltória de dados. Revista de Economia e Administração, 3(1), 15-23.

Morgado, L. B., \& Willey, R. W. (2008). Optimum plant population for maize-bean intercropping system in the Brazilian semi-arid region. Scientia Agricola, 65(5), 474-480. 10.1590/S0103-90162008000500005

Nunes, R. L. C., Bezerra Neto, F., Lima, J. S. S., Barros Júnior, A. P., Chaves, A. P., \& Silva, J. N. (2018). Agro-economic responsiveness of radish associations with cowpea in the presence of different amounts of Calotropis procera, spatial arrangements and agricultural crops. Ciência e Agrotecnologia, 42(4):350-364. 10.1590/1413-70542018424010318

Oliveira, K. J. B., Lima, J. S. S., Soares, A. P. S., Bezerra Neto, F., Linhares, P. C. A. (2015). Produção agroeconômica da rúcula fertilizada com diferentes quantidades de Calotropis Procera. Revista Terceiro Incluído, 5(2), 373-384. 10.5216/teri.v5i2.38791

Oliveira, L. A. A., Bezerra Neto, F., Barros Junior, A. P., Silva, M. L. Oliveira, O. F. N., \& Lima, J. S. S. (2017). Agro-economic efficiency of polycultures of arugula-carrot-lettuce fertilized with roostertree at different population density proportions. Revista Brasileira de Engenharia Agrícola e Ambiental, 21(11), 791-797. 10.1590/1807-1929/agriambi.v21n11p791-797

Oliveira, M. K. T., Bezerra Neto, F., Barros Junior, A. P., Moreira, J.N., Sá, J. R., \& Linhares, P. C. F. (2012). Agroeconomic performance of carrot fertilized with scarlet starglory (Merremia aegyptia). Horticultura Brasileira, 30(3), 433-439. 10.1590/S0102-05362012000300013

Oseni, T. O (2010). Evaluation of sorghum-cowpea intercrop productivity in savanna agro-ecology using competition indices. Journal of Agricultural Science, 2(3), 230-234. 10.5539/jas.v2n3p229

Passos, F. D. A, Nunes, J., Boiago, N. P., Zanatta, F. S., Correa Junior, E. O., Araújo, L. R. V., Silveira, H. T. N., \& Lima, G. B. (2019). Produtividade de milho em diferentes populações de plantio. Revista Cultivando o Saber, 12, 1-11.

Pereira, M. F. S., Bezerra Neto, F., Pontes, F. S. T., Linhares, P. C. F., Silva, M. L., \& Silva, I. N. (2016). Productive performance of cowpea-radish intercropping under different amounts of rooster tree biomass incorporated into the soil. Revista Brasileira de Engenharia Agrícola e Ambiental, 20(11), 965971. 10.1590/1807-1929/agriambi.v20n11p965-971

Rêgo, L. G. S., Martins, C. M., Silva, E. F., Silva, J. J. A., \& Lima, R. N. S. (2016). Pedogenesis and soil classification of an experimental farm in Mossoró, state of Rio Grande do Norte, Brazil. Revista Caatinga, 29(4), 1036-1042. 10.1590/1983-21252016v29n430rc

Rezende, B. L. A., Barros Júnior, A. P., Cecílio Filho, A. B., Pôrto, D. R. Q., \& Martins, M. I. E. G. (2009). Custo de produção e rentabilidade das culturas de alface, rabanete, rúcula e repolho em cultivo solteiro e consorciadas com pimentão. Ciência e Agrotecnologia, 33(1), 305-312. 10.1590/S141370542009000100042

Silva, A. F. A. da, Souza, E. G. F., Santos, M. G. dos, Barros Júnior, A. P., Bezerra Neto, F., \& Silveira, L. M. da. (2015) Rentabilidade do rabanete adubado com flor-de-seda em duas épocas de cultivo no semiárido de Pernambuco. Amazonian Journal of Agricultural and Environmental Sciences, 58(2), 198-207. $10.4322 /$ rca. 1761

Silva, J. N., Bezerra Neto, F., Lima, J. S. S., Chaves, A. P., Nunes, R. L. C., Rodrigues, G. S. O., Lino, V. A. S., Sá, J. M., \& Santos, E. C. (2021). Sustainability of carrot-cowpea intercropping systems through optimization of green manuring and spatial arrangements. Ciência Rural, 51(1), 1-13. $10.1590 / 0103-8478 \mathrm{cr} 20190838$

Silva, J. N., Bezerra Neto, F., Lima, J. S. S., Rodrigues, G. S. O., Barros Júnior, A. P., \& Chaves, A. P. (2017). Combinations of coriander and salad rocket cultivars in bicropping systems intercropped with carrot cultivars. Revista Caatinga, 30(1), 125-135. doi.org/10.1590/1983-21252017v30n114rc

Systat Software. (2002). Table curve 2D and 3D. MMIV Systat Software Inc.

Willey, R. W. (1979). Intercropping - its importance and research needs. Part 1. Competition and yield advantages. Field Crop Abstracts, 32(1), 1-10.

Willey, R. W., \& Osiru, D. S. 1972. Studies on mixtures of maize and beans (Phaseolus vulgaris) with particular reference to plant population. The Journal of Agricultural Science, 79(3), 517-529. 10.1017/S0021859600025909 
Research, Society and Development, v. 10, n. 5, e5310514867, 2021

(CC BY 4.0) | ISSN 2525-3409 | DOI: http://dx.doi.org/10.33448/rsd-v10i5.14867

Zhang, W., Ahanbieke, P., Wang, B. J., Gan, Y. W., Li, L. H., Christie, P., \& Li, L. (2015). Temporal and spatial distribution of roots as affected by interspecific interactions in a young walnut/wheat alley cropping system in northwest China. Agroforestry Systems, 89(2), 327-343. 10.1007/s10457-0149770-x 